\title{
P-T evolution of metapelites from the Guarguaraz Complex, Argentina: evidence for Devonian crustal thickening close to the western Gondwana margin
}

\author{
Hans-Joachim Massonne1, Mauricio Calderón ${ }^{2}$
}

\author{
${ }^{1}$ Institut für Mineralogie und Kristallchemie, Universität Stuttgart, Azenbergstr. 18, D-70174 Stuttgart, Germany. \\ h-j.massonne@mineralogie.uni-stuttgart.de \\ 2 Departamento de Geología, Universidad de Chile, Casilla 13518, Correo 21, Santiago, Chile. \\ Dirección actual: Servicio Nacional de Geología y Minería, Avda. Santa María 0104, Providencia, Santiago, Chile. \\ caldera@esfera.cl; mcalderon@sernageomin.cl
}

\begin{abstract}
In the Guarguaraz Complex of the Argentine Frontal Cordillera (latitude $33.3^{\circ} \mathrm{S}$ ) serpentinite lenses, metabasites, and garnet-bearing metasedimentary rocks occur. The corresponding Devonian metamorphic event was assigned to the formation of an accretionary wedge by previous authors. We have tested this hypothesis by investigating the metamorphic evolution of a pelite from this complex. Garnet in this rock shows a well evolved prograde zoning. Potassic white mica with Si contents between 3.38 (core) and 3.12 (rim) per formula unit, biotite, quartz and plagioclase, which have formed late blasts at the expense of amphibole, coexist with this phase. On the basis of P-T pseudosections and water-absent equilibria, we have estimated the subsequent P-T path for the studied metapelite. The garnet core formed at about $8 \mathrm{kbar}$ and $470-500^{\circ} \mathrm{C}$. After nearly isothermal burial to $45 \mathrm{~km}(13.5 \mathrm{kbar})$ where Si-rich phengites grew, temperatures increased followed by exhumation and an overprint stage at $8 \mathrm{kbar}$ and $565^{\circ} \mathrm{C}$. This P-T path is not compatible with the idea of an accretionary wedge complex. It is more likely that the high-pressure conditions were attained by thickening of continental crust when the hypothetical Chilenia terrane collided with the continental margin of western Gondwana in Devonian times.
\end{abstract}

Keywords: Metapelite, Garnet, Phengite, High-Pressure Metamorphism, Argentine Frontal Cordillera, Devonian.

RESUMEN. Evolución P-T de metapelitas del Complejo Guarguaraz, Argentina: evidencia para el engrosamiento cortical Devónico en cercanías del margen occidental de Gondwana. En el Complejo Guarguaraz, ubicado en la Cordillera Frontal de Argentina (latitud $33,3^{\circ} \mathrm{S}$ ), se encuentran lentes de serpentinita, metabasitas y metasedimentitas de granate. De acuerdo con autores previos, el evento metamórfico asociado ha sido asignado a la formación de un complejo de prisma de acreción en el Devónico. Esta hipótesis ha sido evaluada con el estudio metamórfico de una metapelita del complejo. El granate en la roca muestra una zonación prógrada bien desarrollada. Micas blancas potásicas, con contenidos de Si entre 3,38 (núcleo) y 3,12 (borde) por fórmula unitaria, biotita, cuarzo y plagioclasa, coexisten con granate. Sobre la base de seudosecciones de presión y temperatura y equilibrios anhidros, hemos estimado la trayectoria P-T para la metapelita estudiada. El núcleo del granate se formó en condiciones cercanas a los 8 kbar y $470-500^{\circ} \mathrm{C}$. Después de un enterramiento isotermal hasta $45 \mathrm{~km}(13,5 \mathrm{kbar})$, condiciones en las que la fengita rica en Si se formó, aumentó la temperatura y ocurrió la exhumación y una etapa de sobreimposición metamórfica a 8 kbar y $560^{\circ} \mathrm{C}$. Esta trayectoria P-T no es compatible con el desarrollo de un complejo de prisma de acreción. Es más probable que las condiciones de alta presión fueran alcanzadas durante el engrosamiento de la corteza continental cuando el hipotético terreno de Chilenia colisionó con el margen continental de Gondwana en el Devónico. 


\section{Introduction}

Fragments of Late Palaeozoic to Mesozoic accretionary complexes (Fig. 1a) occur along the Coastal Cordillera of central and southern Chile (Hervé, 1988). These complexes are characterized by phengite-bearing low-temperature, highpressure rocks (Massonne et al., 1996; Willner et al., 2000, 2004a). The occurrences of the accretionary complexes are compatible with continuous subduction of oceanic crust under the western Gondwana margin (Willner, 2005) and a more or less constant position of the related magmatic arc since Carboniferous times. Rocks of an accretionary wedge complex were, however, also reported from the Argentine Frontal Cordillera, for instance by López and Gregori (2004) from the Guarguaraz Complex (Fig. 1). The position of this accretionary complex, different to those of the Chilean Coastal Cordillera, could be also explained by subduction of oceanic crust which, however, was situated between Gondwana and the so far hypothetical microcontinent Chilenia (Ramos et al., 1984). These continental plates finally collided already in the Devonian (Davis et al., 1999) supported by $\mathrm{Rb} / \mathrm{Sr}$ data of Basei et al. (1998) who assigned Middle to Late Devonian ages to the last metamorphic episode in the Frontal Cordillera.

In order to test the idea that the rocks of the Guarguaraz Complex represent those of an accretionary complex, we have sampled various rock types from two sites of the southwestern margin of this complex (Fig. 1b) concentrating on mineral assemblages with garnet. The observed field relations are characterized by sedimentary sequences in which serpentinite lenses and corresponding wall rocks, such as talc deposits (Gregori and Bjerg, 1992) exploited in several open mines, are embedded. The sedimentary sequences consist mainly of metapsammopelites, calcschists, and minor metabasites. The protoliths of the sedimentary rocks are assumed to have been deposited in active marginal basins (López et al., 1999). The metabasites could have been former mid-ocean ridge basalts (Gregori et al., 1997) although the corresponding geochemical data are somewhat ambiguous.

\section{Petrography of metapelitic rocks}

A thin-section study of the sampled metasediments revealed that either metamorphic marls, containing abundant amphibole and epidote, or Capoor metapelites had been taken. The latter rocks contain the ordinary mineral assemblage biotitemuscovite/phengite-garnet-plagioclase-quartz. For a detailed study, we selected such a metapelite (sample GC04-27b, coordinates: $33^{\circ} 20.23^{\prime}$ 'S$69^{\circ} 26.78^{\prime} \mathrm{W}$, Datum: S. Am. 69) because of its fresh garnets up to several $\mathrm{mm}$ in diameter (Fig. 2). The

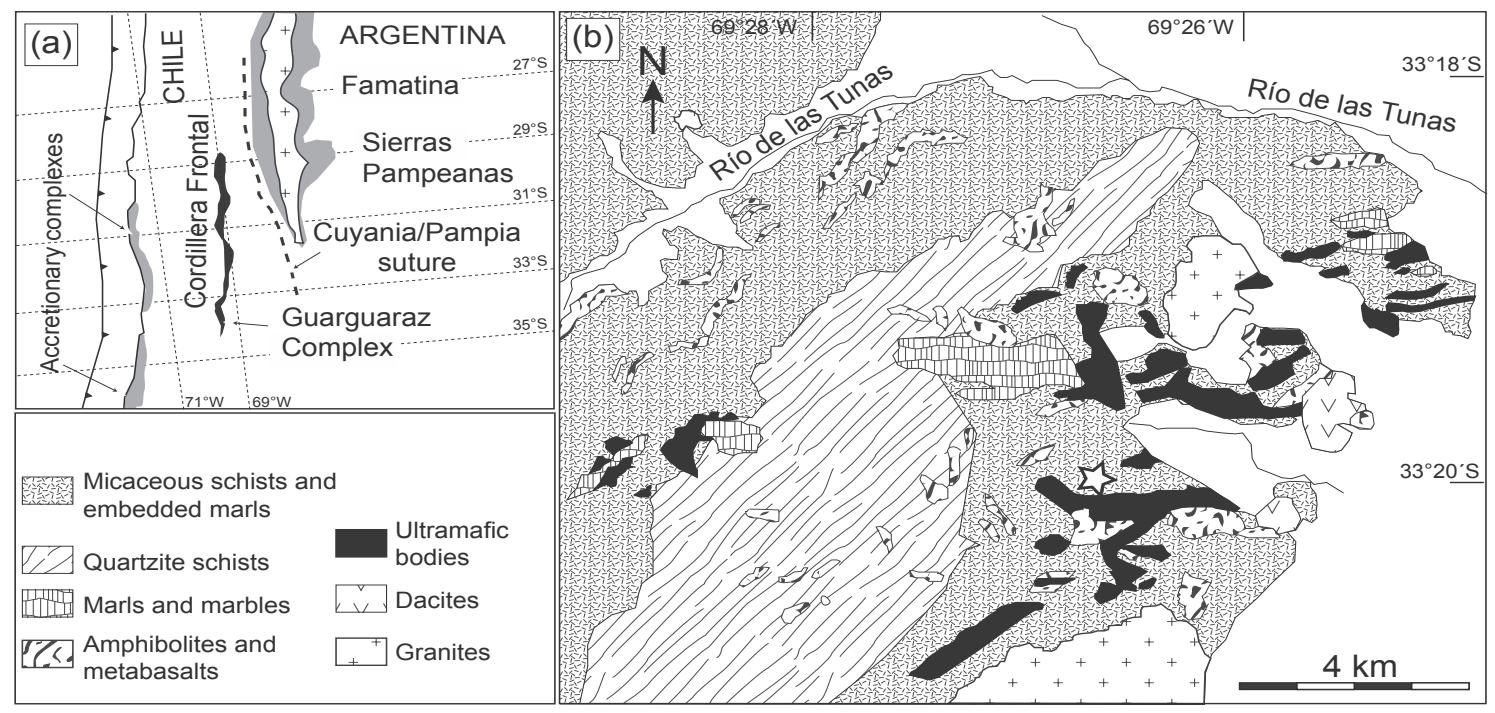

FIG. 1. Simplified geological maps of a. western South America between latitudes $24^{\circ}$ and $37^{\circ} \mathrm{S}$; b. the Guarguaraz Complex according to López and Gregori (2004). The sampling site is shown by a star. 
modal content of garnet, which includes abundant quartz, many small titanite grains (in the core), and some biotite, rutile, chlorite and epidote, amounts to about 2 vol\%. Biotite ( $12 \mathrm{vol} \%)$ and potassic white mica (25-30 vol\%) show grain sizes up to 1 $\mathrm{mm}$. The micas are distinctly oriented as a result of at least two deformational events at relatively high temperatures (Fig. 3). At these temperatures, postdeformational (stage II and/or younger, see section

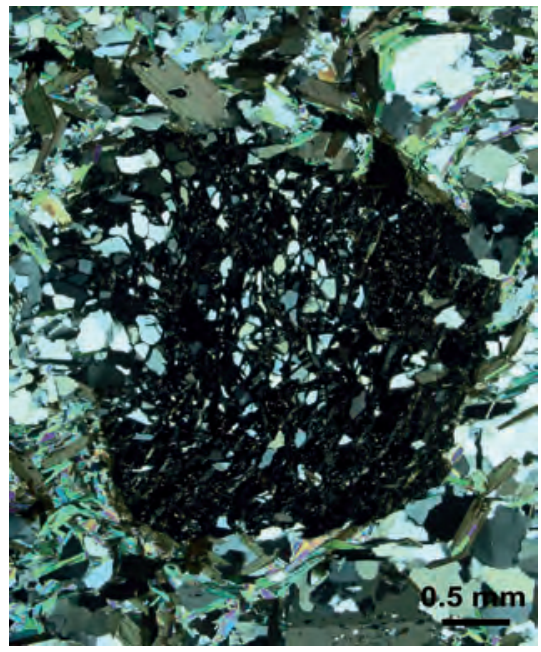

FIG. 2. Photomicrograph of a garnet porphyroblast in sample GC04-27b under crossed nicols. Most inclusions in garnet are quartz. Several titanite inclusions also occur in the garnet core.



FIG. 3. Photomicrograph of an area with distinctly oriented biotite and phengite in sample GC04-27b under crossed nicols.
3.2) porphyroblasts of plagioclase (Fig. 4) formed. These blasts ( $\sim 7 \mathrm{vol} \%$ ) can show grain sizes of a few $\mathrm{mm}$. Apatite, chlorite, epidote, quartz, titanite, both micas, and rarely significantly corroded bluishgreenish amphibole occur as inclusions mainly in the core of the plagioclase blasts. Accessories in the rock matrix are apatite, rutile (partly transformed to ilmenite), epidote and chlorite.

\section{Chemical compositions of minerals in the selected metapelitic sample}

\subsection{Analytical techniques}

The compositions of phases in sample GC0427b were analysed by a Cameca SX100 electron microprobe (EMP) with 5 wavelength-dispersive systems (WDS). We determined the concentrations of $\mathrm{F}, \mathrm{Na}, \mathrm{Mg}, \mathrm{Al}, \mathrm{Si}, \mathrm{K}, \mathrm{Ca}, \mathrm{Ti}, \mathrm{Cr}, \mathrm{Mn}, \mathrm{Fe}$ and $\mathrm{Ba}$. Counting times were $20 \mathrm{~s}$ at the peak and the background. For some elements (Ti, Cr, Mn and $\mathrm{Fe}$ ) large PET and LiF spectrometer crystals were applied. We used natural minerals, glasses (e.g., $\mathrm{Ba}$ glass for the $\mathrm{BaL} \alpha_{1}$-peak), and pure oxides as standards. The applied acceleration voltage and beam current were $15 \mathrm{kV}$ and $15 \mathrm{nA}$, respectively. Beam diameter was about $5 \mu \mathrm{m}$. For the analysis of tiny inclusion grains a focussed beam and 10 $\mathrm{nA}$ beam current were used. The PaP correction procedure provided by Cameca was applied. Concentration maps for major elements (number

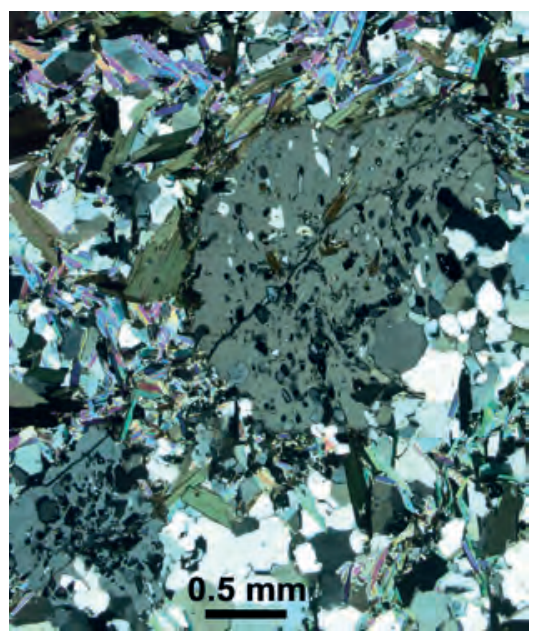

FIG. 4. Photomicrograph of an albite porphyroblast in sample GC04-27b under crossed nicols. 
of simultaneously prepared maps according to the number of WDS) were obtained by step-wise movement of the thin section under the electron beam $(15 \mathrm{kV}, 15 \mathrm{nA})$ of the EMP and subsequent computer aided evaluation (e.g., Bernhardt et al., 1995). Counting times per step were 100 or $200 \mathrm{~ms}$. The energy-dispersive system (EDS) of the EMP served as mean of identification of phases during the selection of spots for full analyses.

\subsection{Analytical results}

In the investigated sample, large garnets display a concentric zonation (Fig. 5) with a relatively high $\mathrm{Mn}$ content in the core (metamorphic stage $\mathrm{I}$, the inner core related to stage Ia is composed of $25 \mathrm{~mol} \%$ grossular (+andradite), $2 \mathrm{~mol} \%$ pyrope, $51 \mathrm{~mol} \%$ almandine, $22 \mathrm{~mol} \%$ spessartine). The garnet rim composition (metamorphic stage II: $25 \mathrm{~mol} \%$ grossular (+andradite), $4 \mathrm{~mol} \%$ pyrope, $61 \mathrm{~mol} \%$ almandine, $10 \mathrm{~mol} \%$ spessartine) is significantly richer in $\mathrm{Mg}$ and poorer in $\mathrm{Mn}$ than the core composition (Table 1). The outermost rim (metamorphic stage III), however, shows a slight increase in $\mathrm{Mn}$ reaching $13 \mathrm{~mol} \%$ spessartine component in garnet again.

Biotite grains are slightly zoned with $\mathrm{X}_{\mathrm{Mg}}$ $(=\mathrm{Mg} /(\mathrm{Mg}+\mathrm{Fe})$ between 0.43 and 0.46 (Table 1). Unfortunately, a clear core-rim or early-late (stages I to III) compositional relation was not discernible. On the contrary, potassic white mica can easily be subdivided into two generations (Fig. 6). The older generation is phengitic (stages I and II: Si per formula unit $(\mathrm{pfu})=3.30-3.38, \mathrm{X}_{\mathrm{Mg}}=0.51-0.58$, $\mathrm{X}_{\mathrm{Na}}(=\mathrm{Na} / \mathrm{Na}+\mathrm{K}+\mathrm{Ba}) \sim 0.05$, Table 1) whereas the younger generation, overgrowing older grains during a post-deformational event, is muscovitic (stage III: $\mathrm{Si}=3.12-3.22 \mathrm{pfu}, \mathrm{X}_{\mathrm{Mg}}=0.40-0.47, \mathrm{X}_{\mathrm{Na}}$ $\sim 0.075$ ). In general, the compositional trend from an early metamorphic stage to a late one seems to be characterized by a decrease of the Si content accompanied by a decrease of the $\mathrm{Mg}+\mathrm{Fe}$ contents due to the Tschermak's substitution. $\mathrm{X}_{\mathrm{Mg}}$ and $\mathrm{X}_{\mathrm{Na}}$ values decrease and increase, respectively, from phengite towards late stage muscovite. Potassic white mica enclosed in the core of plagioclase blasts is phengite with $\mathrm{Si} \geq 3.30$ pfu.

Plagioclase is nearly pure albite (Table 1). The rim of plagioclase blasts shows the highest $\mathrm{CaO}$ contents of about $0.5 \mathrm{wt} \%$. Titanite (Table 2) contains some $\mathrm{Al}\left(\mathrm{Al}_{2} \mathrm{O}_{3} \sim 2 \mathrm{wt} \%\right)$ and exceptionally much $\mathrm{Fe}\left(\mathrm{Fe}_{2} \mathrm{O}_{3}=1.0 \mathrm{wt} \%\right.$ or somewhat higher).
Chlorites (Table 2) in the rock matrix and enclosed in minerals are similar in composition $(\mathrm{Si} \sim 2.65$, $\mathrm{X}_{\mathrm{Mg}}=0.5-0.46$ ). Analysed matrix chlorite always shows some $\mathrm{K}$ and $\mathrm{Ca}$ as a result of partial alteration to vermiculite/smectite which is already discernable by optical inspection through higher interference colours under crossed nicols. Epidote grains, which are rarely larger than $50 \mu \mathrm{m}$ are usually cloudy in the core and clear at the rim. According to the observed deficit in $\mathrm{Ca}$ (Table 2) and small $\mathrm{La}$ and Ce peaks in the EDS spectrum, the core is more allanitic than the rim. Several analysed amphibole relics enclosed in plagioclase are similar in composition. According to the calculated $\mathrm{Fe}^{2+}-\mathrm{Fe}^{3+}$ contents given in table 2, the amphibole is a tschermakite (Leake et al., 1997).

\section{Pressure-temperature estimates}

\subsection{Methods}

To determine P-T conditions of the metamorphic events in the Guarguaraz Complex water-conserving equilibria were considered. We calculated the P-T positions of such equilibria with the computer software package PTGIBBS (Brandelik and Massonne, 2004) using the thermodynamic data-set by Berman (1988) augmented by compatible data for end members of garnet and mica (e.g., Massonne and Szpurka, 1997). The non-ideal garnet solid-solution model garnetmas, the non-ideal solid-solution model WhiteMica for potassic white mica (for molar fractions of corresponding components see table 1), and activities for annite and phlogopite (Table 1), calculated, for instance, according to ( $\mathrm{Fe}$ $(=$ number of $\mathrm{Fe}$ cations $\mathrm{pfu}) / 3)^{3} \cdot 1.3$ as proposed by Massonne (1995), were applied.

Among the numerous water-conserving equilibria in which the garnet components al-mandine, grossular, and pyrope, the white mica components muscovite, $\mathrm{Mg}$-Al-celadonite, $\mathrm{Fe}^{2+}$-Al-celadonite, and paragonite, the dark mica components phlogopite and annite, the plagioclase components albite and anorthite, and quartz $\left(\mathrm{a}_{\text {quartz }}=1.0\right)$ participate, we have selected the subsequent four equilibria, which are of geobarometric relevance:

(E1) 2 Almandine $+3 \mathrm{Mg}$-Al-Celadonite $=6$ Quartz+1 Pyrope+1 Muscovite+2 Annite.

(E2) 1 Almandine $+3 \mathrm{Mg}$-Al-Celadonite $=6$ Quartz+1 Phlogopite+1 Muscovite+1 Annite. 

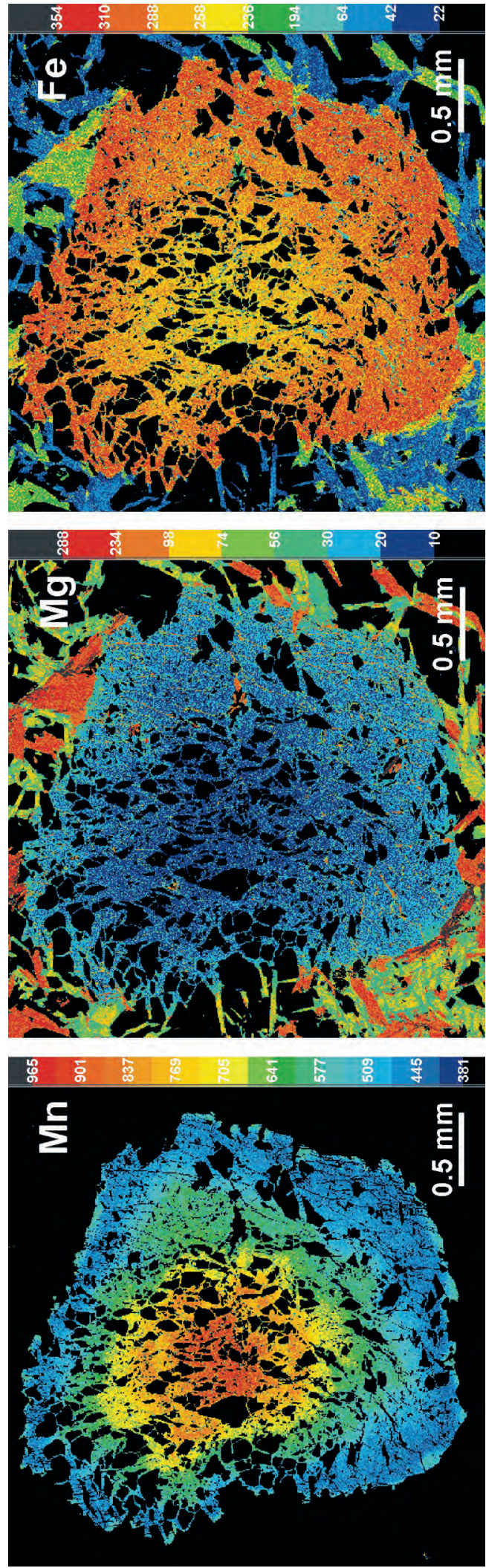
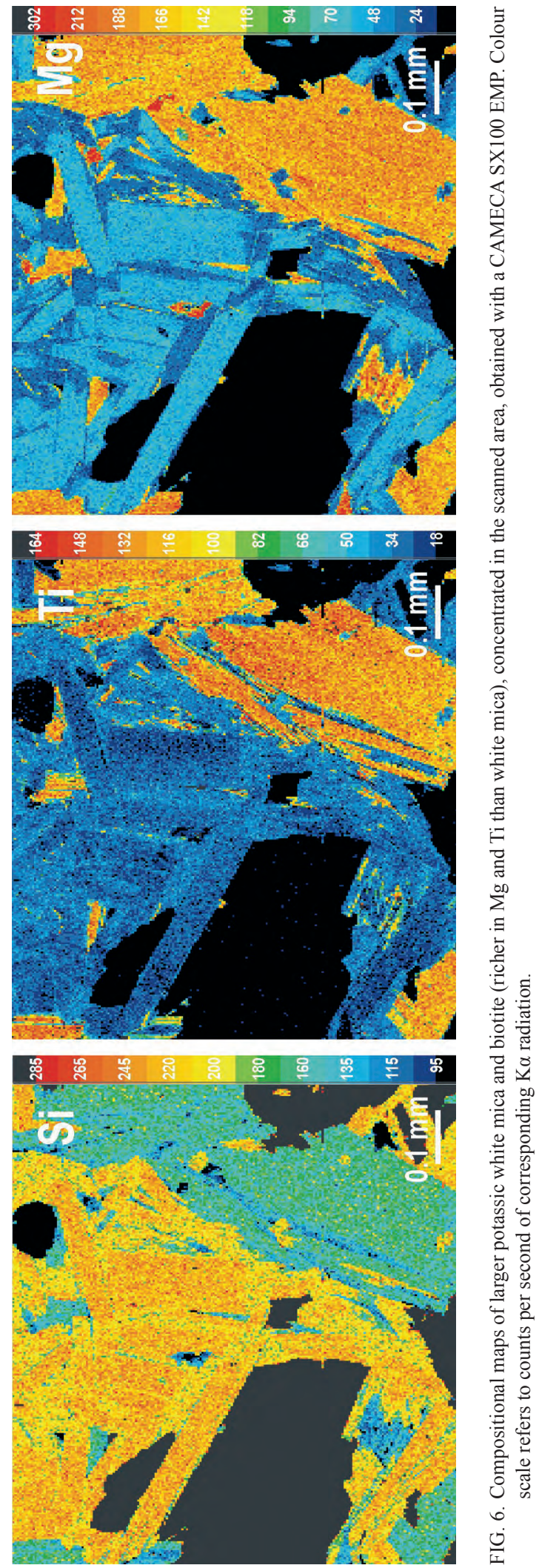
TABLE 1. REPRESENTATIVE ELECTRON MICROPROBE ANALYSES OF MINERALS IN METAPELITIC SAMPLE GC04-27B.

\begin{tabular}{|c|c|c|c|c|c|c|c|c|c|c|c|c|c|}
\hline \multirow{2}{*}{$\begin{array}{l}\text { Mineral } \\
\text { Comment }\end{array}$} & \multirow[b]{2}{*}{ core } & \multicolumn{3}{|c|}{ Garnet } & & \multicolumn{3}{|c|}{ Muscovite/Phengite } & \multicolumn{3}{|c|}{ Biotite } & & \multirow[t]{2}{*}{ Plagioclase } \\
\hline & & $\begin{array}{l}\text { inter- } \\
\text { med. }\end{array}$ & rim & $\begin{array}{c}\text { outermost } \\
\text { rim }\end{array}$ & & core & $\begin{array}{l}\text { inclusion } \\
\text { in } \mathrm{Oz}\end{array}$ & rim & & core & & & \\
\hline Sample No. & $7-5$ & $7-20$ & $7-29$ & $7-30$ & & $5-41$ & $5-36$ & $5-57$ & & $5-16$ & $5-27$ & & $5-37$ \\
\hline $\mathrm{SiO}_{2}$ & 36.78 & 37.06 & 36.94 & 36.83 & & 50.21 & 48.88 & 45.88 & & 35.33 & 36.53 & & 69.16 \\
\hline $\mathrm{TiO}_{2}$ & 0.17 & 0.14 & 0.11 & 0.05 & & 0.25 & 0.36 & 0.44 & & 1.82 & 1.86 & & 0.00 \\
\hline $\mathrm{Al}_{2} \mathrm{O}_{3}$ & 20.58 & 20.79 & 20.74 & 20.80 & & 26.70 & 28.15 & 31.99 & & 16.74 & 16.74 & & 19.70 \\
\hline $\mathrm{Cr}_{2} \mathrm{O}_{3}$ & 0.01 & 0.03 & 0.01 & 0.03 & & 0.00 & 0.00 & 0.00 & & 0.00 & 0.00 & & 0.00 \\
\hline $\mathrm{Fe}_{2} \mathrm{O}_{3}$ & 1.14 & 1.16 & 1.14 & 0.95 & & --- & -- & -- & & -- & -- & & 0.00 \\
\hline $\mathrm{FeO}$ & 22.98 & 25.68 & 27.72 & 27.21 & & 4.52 & 4.11 & 3.78 & & 22.22 & 21.11 & & -- \\
\hline $\mathrm{MnO}$ & 9.59 & 6.44 & 4.64 & 5.81 & & 0.00 & 0.05 & 0.01 & & 0.21 & 0.19 & & 0.00 \\
\hline $\mathrm{MgO}$ & 0.56 & 0.69 & 0.95 & 1.22 & & 2.98 & 2.63 & 1.39 & & 9.89 & 10.03 & & 0.00 \\
\hline $\mathrm{CaO}$ & 8.82 & 9.36 & 8.76 & 7.82 & & 0.00 & 0.00 & 0.00 & & 0.00 & 0.02 & & 0.21 \\
\hline $\mathrm{Na}_{2} \mathrm{O}$ & 0.03 & 0.05 & 0.02 & 0.00 & & 0.35 & 0.40 & 0.57 & & 0.11 & 0.08 & & 12.13 \\
\hline $\mathrm{K}_{2} \mathrm{O}$ & -- & -- & -- & -- & & 10.39 & 10.54 & 10.31 & & 8.97 & 9.40 & & 0.08 \\
\hline $\mathrm{BaO}$ & --- & --- & --- & --- & & 0.27 & 0.26 & 0.51 & & 0.19 & 0.19 & & 0.01 \\
\hline $\mathrm{F}$ & --- & -- & -- & --- & & 0.02 & 0.08 & 0.00 & & 0.30 & 0.15 & & -- \\
\hline $\mathrm{H}_{2}$ Ocalc & --- & -- & -- & -- & & 4.45 & 4.40 & 4.40 & & 3.74 & 3.86 & & -- \\
\hline Total (corr.) & 100.67 & 101.40 & 101.03 & 100.71 & & 100.14 & 99.82 & 99.29 & & 99.40 & 100.11 & & 101.29 \\
\hline $\mathrm{Si}$ & 5.854 & 5.838 & 5.840 & 5.834 & & 3.375 & 3.301 & 3.124 & & 2.729 & 2.783 & & 2.988 \\
\hline $\mathrm{Al}^{(\mathrm{IV})}$ & --- & --- & --- & --- & & 0.625 & 0.699 & 0.876 & & 1.271 & 1.217 & & 1.003 \\
\hline $\mathrm{Ti}$ & 0.021 & 0.017 & 0.012 & 0.006 & & 0.012 & 0.018 & 0.023 & & 0.106 & 0.107 & & 0.000 \\
\hline $\mathrm{Al}^{(\mathrm{VI})}$ & 3.862 & 3.859 & 3.864 & 3.884 & & 1.490 & 1.542 & 1.691 & & 0.253 & 0.286 & & -- \\
\hline $\mathrm{Cr}$ & 0.002 & 0.004 & 0.001 & 0.003 & & 0.000 & 0.000 & 0.000 & & 0.000 & 0.000 & & 0.000 \\
\hline $\mathrm{Fe}^{\left(3^{+}\right)}$ & 0.137 & 0.137 & 0.135 & 0.113 & & --- & --- & --- & & --- & -- & & 0.000 \\
\hline $\mathrm{Fe}^{(2+)}$ & 3.060 & 3.382 & 3.664 & 3.605 & & 0.254 & 0.232 & 0.215 & & 1.435 & 1.345 & & --- \\
\hline $\mathrm{Mn}$ & 1.293 & 0.859 & 0.622 & 0.780 & & 0.000 & 0.003 & 0.001 & & 0.014 & 0.012 & & 0.000 \\
\hline $\mathrm{Mg}$ & 0.133 & 0.163 & 0.224 & 0.289 & & 0.299 & 0.265 & 0.141 & & 1.139 & 1.139 & & --- \\
\hline Sum $^{(\mathrm{IV}+\mathrm{VI})}$ & --- & -- & --- & --- & & 6.055 & 6.060 & 6.070 & & 6.947 & 6.889 & & 3.991 \\
\hline $\mathrm{Ca}$ & 1.505 & 1.581 & 1.483 & 1.327 & & 0.000 & 0.000 & 0.000 & & 0.000 & 0.001 & & 0.010 \\
\hline $\mathrm{Na}$ & 0.009 & 0.015 & 0.007 & 0.000 & & 0.046 & 0.052 & 0.075 & & 0.016 & 0.012 & & 1.016 \\
\hline K & --- & --- & -- & -- & & 0.891 & 0.908 & 0.895 & & 0.884 & 0.914 & & 0.005 \\
\hline $\mathrm{Ba}$ & --- & --- & --- & -- & & 0.007 & 0.007 & 0.014 & & 0.006 & 0.006 & & 0.000 \\
\hline Sum $^{\text {(VIII-XII) }}$ & 6.000 & 6.000 & 6.000 & 6.000 & & 0.944 & 0.967 & 0.983 & & 0.906 & 0.933 & & 1.031 \\
\hline $\mathrm{F}$ & -- & -- & -- & -- & & 0.004 & 0.016 & 0.000 & & 0.073 & 0.037 & & --- \\
\hline $\mathrm{H}$ & --- & -- & --- & --- & & 1.996 & 1.984 & 2.000 & & 1.927 & 1.963 & & --- \\
\hline \multicolumn{14}{|l|}{ Components } \\
\hline Xgross & 0.2509 & 0.2634 & 0.2472 & 0.2211 & $\mathrm{Xms}$ & 0.4936 & 0.5520 & 0.6798 & $\mathrm{xAl}$ & 0.1264 & 0.1430 & Xan & 0.0097 \\
\hline Xpyrop & 0.0222 & 0.0271 & 0.0373 & 0.0481 & Xtri & 0.0553 & 0.0602 & 0.0703 & $\mathrm{aPhl}$ & 0.0712 & 0.0712 & $\mathrm{Xab}$ & 0.9858 \\
\hline Xalm & 0.5099 & 0.5637 & 0.6107 & 0.6008 & Xmg-al-cel & 0.2069 & 0.1643 & 0.0544 & aAnn & 0.1424 & 0.1171 & $\mathrm{Xkf}$ & 0.0045 \\
\hline Xspess & 0.2155 & 0.1432 & 0.1036 & 0.1299 & Xfe-al-cel & 0.1756 & 0.1439 & 0.0831 & --- & --- & --- & -- & --- \\
\hline $\mathrm{xAl}$ & 0.9654 & 0.9647 & 0.9659 & 0.9709 & Xparag & 0.0487 & 0.0540 & 0.0760 & --- & --- & --- & -- & --- \\
\hline-- & --- & --- & --- & --- & Xrest & 0.0200 & 0.0256 & 0.0363 & --- & --- & --- & --- & --- \\
\hline-- & -- & -- & -- & -- & $\mathrm{XOH}$ & 0.9980 & 0.9920 & 0.9999 & --- & --- & --- & -- & --- \\
\hline
\end{tabular}

The analyses were re-calculated to structural formulae (garnet: $24 \mathrm{O}, 10$ six-and eight-fold coordinated cations; mica: 22 val.; feldspar: $8 \mathrm{O}$ ) and various parameters (mainly molar fractions $\mathrm{X}$ of end member components). 
TABLE 2. REPRESENTATIVE ELECTRON MICROPROBE ANALYSES (IN WT\%) OF ACCESSORY MINERALS IN METAPELITIC SAMPLE GC04-27B.

\begin{tabular}{|c|c|c|c|c|c|c|}
\hline \multirow{2}{*}{$\begin{array}{l}\text { Mineral } \\
\text { Comment }\end{array}$} & \multicolumn{2}{|c|}{ Epidote } & \multirow{2}{*}{$\begin{array}{l}\text { Amphibole } \\
\text { incl. in Plag. }\end{array}$} & \multirow{2}{*}{$\begin{array}{c}\text { Titanite } \\
\text { incl. in Amph. }\end{array}$} & \multicolumn{2}{|c|}{ Chlorite } \\
\hline & core & rim & & & incl. in garnet & matrix \\
\hline Analysis No. & $11-8$ & $11-7$ & $1-8$ & $1-4$ & $1-14$ & $1-18$ \\
\hline $\mathrm{SiO}_{2}$ & 37.97 & 38.43 & 43.50 & 30.10 & 24.26 & 25.17 \\
\hline $\mathrm{TiO}_{2}$ & 0.05 & 0.11 & 0.40 & 36.94 & 0.08 & 0.08 \\
\hline $\mathrm{Al}_{2} \mathrm{O}_{3}$ & 21.56 & 26.06 & 12.16 & 2.02 & 19.84 & 20.56 \\
\hline $\mathrm{Fe}_{2} \mathrm{O}_{3}$ & 16.38 & 11.19 & 9.76 & 0.96 & -- & -- \\
\hline $\mathrm{FeO}$ & --- & --- & 11.48 & --- & 27.30 & 27.82 \\
\hline $\mathrm{Mn}_{2} \mathrm{O}_{3}$ & 0.46 & 0.31 & --- & 0.00 & --- & --- \\
\hline $\mathrm{MnO}$ & --- & --- & 0.36 & --- & 0.22 & 0.34 \\
\hline $\mathrm{MgO}$ & 0.03 & 0.03 & 8.07 & 0.00 & 15.07 & 13.61 \\
\hline $\mathrm{CaO}$ & 21.46 & 22.71 & 10.30 & 27.57 & --- & --- \\
\hline $\mathrm{Na}_{2} \mathrm{O}$ & 0.02 & 0.03 & 1.34 & 0.03 & -- & --- \\
\hline $\mathrm{K}_{2} \mathrm{O}$ & -- & -- & 0.41 & 0.06 & -- & -- \\
\hline $\mathrm{H}_{2} \mathrm{Ocalc}$ & 1.87 & 1.92 & 2.02 & --- & 11.07 & 11.19 \\
\hline Total & 99.81 & 100.80 & 99.78 & 97.70 & 97.84 & 98.77 \\
\hline $\mathrm{Si}$ & 3.038 & 2.993 & 6.470 & 1.000 & 5.258 & 5.394 \\
\hline $\mathrm{Ti}$ & 0.003 & 0.007 & 0.045 & 0.923 & 0.013 & 0.012 \\
\hline $\mathrm{Al}$ & 2.034 & 2.392 & 2.131 & 0.079 & 5.067 & 5.194 \\
\hline $\mathrm{Fe}^{(3+)}$ & 0.987 & 0.656 & 1.093 & 0.024 & --- & --- \\
\hline $\mathrm{Fe}^{(2+)}$ & --- & --- & 1.428 & --- & 4.948 & 4.986 \\
\hline $\mathrm{Mn}$ & 0.028 & 0.018 & 0.045 & 0.000 & 0.041 & 0.062 \\
\hline $\mathrm{Mg}$ & 0.004 & 0.004 & 1.788 & --- & 4.870 & 4.348 \\
\hline $\mathrm{Ca}$ & 1.840 & 1.895 & 1.642 & 0.982 & --- & --- \\
\hline $\mathrm{Na}$ & 0.003 & 0.005 & 0.386 & 0.002 & --- & --- \\
\hline K & -- & --- & 0.077 & -- & --- & --- \\
\hline $\mathrm{H}$ & 1.000 & 1.000 & 2.000 & --- & 16.000 & 16.000 \\
\hline
\end{tabular}

The analyses were re-calculated to structural formulae (epidote: $12.5 \mathrm{O}$, REE ignored; amphibole: $23 \mathrm{O}, 13$ cations without Ca, $\mathrm{Na}, \mathrm{K}$; titanite: $1 \mathrm{Si}$, $\mathrm{H}_{2} \mathrm{O}$ ignored; chlorite: $28 \mathrm{O}$ ). Barium, $\mathrm{Cr}$, and $\mathrm{F}$ were below detection limit. Analysed contents of $\mathrm{K}_{2} \mathrm{O}+\mathrm{CaO}$ were 0.05 and $0.30 \mathrm{wt} \%$ in chlorite analyses 1-14 and 1-18, respectively.

(E3) 1 Almandine+3 Mg-Al-Celadonite=6 Quartz+1 Muscovite+2 Annite.

(E4) 1 Pyrope+2 Grossular+3 Muscovite+6 Quartz=6 Anorthite+3 Mg-Al-Celadonite.

Two further equilibria were considered which are of geothermometric relevance:

(E5) 1 Almandine+1 Phlogopite=1 Pyrope +1 Annite.

(E6) 1 Almandine+3 Mg-Al-Celadonite $=1$ Pyrope+3 Fe-Al-Celadonite.

For the assemblage garnet-biotite-phengiteplagioclase-quartz in equilibrium, (E1) to (E6) and other equilibria not considered here ought to intersect in a single P-T point for theoretical reasons. However, we found that the calculated equilibria do not intersect precisely. This is because of three reasons: 1. imperfectness of the thermodynamic data (including solid-solution properties), 2. analytical errors using the EMP and 3. problems in relating specific mineral compositions to an equilibrium assemblage. Especially for the latter reason, it is difficult to determine P-T errors of the method. Nevertheless, our estimates of the $1 \sigma$ uncertainties are in the range of $\pm 1 \mathrm{kbar}$ (E1 to E3) and $\pm 20^{\circ} \mathrm{C}$ (E5 and E6). The accuracy is probably twice as high as the corresponding uncertainty. For equilibria, such as (E4), in which a mineral component with very low concentration in the corresponding mineral (anorthite component in albite) participates, the errors could be significantly higher. 
In addition to the above thermodynamic calculations, we applied the $\mathrm{Fe}^{2+}-\mathrm{Mg}$ exchange thermometry for the garnet-biotite pair (based on E5) using the empirical calibration by Kleemann and Reinhardt (1994), implemented in the THERBARO program (Kleemann, 1996. Unpublished, version 3.0, Ruhr-Universitaet Bochum). The error in temperature of this method is assumed to be similar to those of the above thermometric methods.

Several equilibria with $\mathrm{H}_{2} \mathrm{O}$ could be additionally calculated considering the above mentioned mineral components. However, the activity of water $\left(=\mathrm{a}_{\mathrm{H}_{2} \mathrm{O}}\right)$ during metamorphism is uncertain. Thus, we have calculated the subsequent equilibrium for different water activities:

(E7) 2 Paragonite $+3 \mathrm{Mg}$-Al-Celadonite $=3$ Quartz +2 Muscovite +1 Phlogopite +2 Albite +2 $\mathrm{H}_{2} \mathrm{O}$.

The minimum Gibbs energy relation for a specific rock composition was calculated for a net of P-T conditions to prepare a so-called P-T pseudosection. Such pseudosections were calculated with the computer program package PERPLE_X (Connolly, 1990; version from August 2005 downloaded from the internet site http://www.perplex.ethz.ch/) for the system $\mathrm{K}_{2} \mathrm{O}-\mathrm{Na}_{2} \mathrm{O}-\mathrm{CaO}-\mathrm{MgO}-\mathrm{MnO}-\mathrm{FeO}-\mathrm{O}_{2}-$ $\mathrm{Al}_{2} \mathrm{O}_{3}-\mathrm{TiO}_{2}-\mathrm{SiO}_{2}-\mathrm{H}_{2} \mathrm{O}$ and the $\mathrm{P}-\mathrm{T}$ range $4-16 \mathrm{kbar}$ and $400-650^{\circ} \mathrm{C}$. We used the thermodynamic data set of Holland and Powell (1998, updated 2002) for minerals and aqueous fluid. The subsequent solidsolution models (e.g., Powell and Holland, 1999), being compatible with this data set, were selected from the downloaded version of the PERPLE_X solution-model file (newest_format_solut.dat): Bio(HP) for biotite, Chl(HP) for chlorite, Ep(HP) for clinozoisite-epidote, Gt(HP) for garnet, Pheng(HP) for potassic white mica, GlTrTsPg for amphibole, Omph(HP) for omphacite, $\mathrm{Pl}(\mathrm{h})$ for plagioclase, and $\mathrm{Pa}$ for paragonite. Additional solid-solution models were, in fact, considered, but corresponding minerals did not appear in the calculated pseudosections. For the garnet model in newest_format_solut.dat we had enlarged the limit of spessartine content to $30 \mathrm{~mol} \%$. The obtained graphical results (subprograms vertex and psvdraw) were taken as raw data. The final pseudosection was redrawn by smoothing curves as demonstrated by Connolly (2005). We also calculated the P-T position of isopleths for the $\mathrm{Si}$ content in potassic white mica and the molar fractions of garnet components in garnet (subprograms werami and pscontor). The final graphs were obtained also by smoothing the calculated curves. Information on a mineral assemblage at specific P-T conditions could be taken from printable files generated by subprogram vertex.

The chemical composition of rock sample GC04-27b was determined with a PHILIPS PW 2400 X-ray fluorescence (XRF) spectrometer. Finely ground rock powder obtained with a WC dish-and-puck mill was fused with Spectromelt ${ }^{\circledR}$ (ratio 1:9) to prepare glass disks used for the analyses of major elements of the bulk rock. The contents of trace elements (Table 3) were determined employing a powder pellet. For the calculation of the pseudosection the major element composition analysed by XRF was simplified to the above 11-component system and normalized to $100 \%$ (Table 1). Pseudosections were calculated for two different water contents. In one case (A), water was in excess for the here relevant P-T conditions, in the other case a water deficit (B) was considered. The oxygen content of $0.04 \mathrm{wt} \%$ was chosen to account for some epidote with considerable $\mathrm{Fe}^{3+}$ contents (Table 2).

\subsection{Results}

The P-T pseudosection for the $\mathrm{H}_{2} \mathrm{O}$ rich composition A, calculated with PERPLE_X, is displayed in figure 7. In addition, $\mathrm{Si}$ isopleths for potassic white mica in the corresponding mineral assemblages are shown in this pseudosection. Further information is given in figure 8 , exhibiting isopleths for molar fractions of garnet components. These isopleths are also related to the mineral assemblages and rock composition of figure 7. Moreover, we present in table 4 the calculated modal composition for rock composition A and chemical compositions of coexisting minerals at different $\mathrm{P}-\mathrm{T}$ conditions which are relevant to the metamorphic evolution of the Guarguaraz Complex. It turns out that the observed minerals and mineral assemblages in sample GC04-27b appear indeed in the pseudosection for composition A in the considered P-T range of 4-16 kbar and $400-650^{\circ} \mathrm{C}$ as, for instance, the assemblage of the rock matrix (late metamorphic stage) garnetpotassic white mica-biotite-plagioclase-epidoterutile-quartz. This assemblage is compatible with P-T conditions derived earlier by Ruviños et al. (1997). In addition, the analyzed compositions of potassic white mica (Si pfu between 3.12 and 3.38) 
TABLE 3. XRF ANALYSES OF METAPELITE GC04-27B.

\begin{tabular}{|c|c|c|c|c|}
\hline Composition & GC04-27b & & $\mathbf{A}$ & B \\
\hline $\mathrm{SiO}_{2}$ in $\mathrm{wt} \%$ & 69.42 & $\mathrm{SiO}_{2}$ in $\mathrm{wt} \%$ & 69.291 & 70.132 \\
\hline $\mathrm{TiO}_{2}$ & 0.58 & $\mathrm{TiO}_{2}$ & 0.577 & 0.584 \\
\hline $\mathrm{Al}_{2} \mathrm{O}_{3}$ & 13.18 & $\mathrm{Al}_{2} \mathrm{O}_{3}$ & 13.156 & 13.316 \\
\hline $\mathrm{Fe}_{2} \mathrm{O}_{3}$ & 5.88 & $\mathrm{Fe}_{2} \mathrm{O}_{3}$ & 5.278 & 5.342 \\
\hline $\mathrm{MnO}$ & 0.17 & $\mathrm{MnO}$ & 0.173 & 0.175 \\
\hline $\mathrm{MgO}$ & 2.20 & $\mathrm{MgO}$ & 2.195 & 2.222 \\
\hline $\mathrm{CaO}$ & 1.26 & $\mathrm{CaO}$ & 1.260 & 1.275 \\
\hline $\mathrm{Na}_{2} \mathrm{O}$ & 0.77 & $\mathrm{Na}_{2} \mathrm{O}$ & 0.766 & 0.775 \\
\hline $\mathrm{K}_{2} \mathrm{O}$ & 4.28 & $\mathrm{~K}_{2} \mathrm{O}$ & 4.267 & 4.319 \\
\hline $\mathrm{P}_{2} \mathrm{O}_{5}$ & 0.66 & $\mathrm{O}_{2}$ & 0.040 & 0.040 \\
\hline $\mathrm{H}_{2} \mathrm{O}$ & 2.11 & $\mathrm{H}_{2} \mathrm{O}$ & 2.999 & 1.820 \\
\hline $\mathrm{C}$ & 0.03 & --- & --- & -- \\
\hline Sum & 100.52 & Sum & 100.00 & 100.00 \\
\hline Sc in ppm & 8 & -- & --- & -- \\
\hline V & 49 & --- & --- & -- \\
\hline $\mathrm{Cr}$ & 60 & --- & --- & -- \\
\hline $\mathrm{Ni}$ & 12 & -- & -- & -- \\
\hline $\mathrm{Zn}$ & 77 & --- & --- & -- \\
\hline $\mathrm{Ga}$ & 17 & -- & --- & -- \\
\hline $\mathrm{Rb}$ & 140 & --- & --- & -- \\
\hline $\mathrm{Sr}$ & 97 & -- & -- & -- \\
\hline Y & 24 & --- & --- & -- \\
\hline $\mathrm{Zr}$ & 144 & -- & -- & -- \\
\hline $\mathrm{Nb}$ & 12 & -- & --- & -- \\
\hline Sn & 5 & --- & --- & -- \\
\hline $\mathrm{Ba}$ & 1,013 & -- & -- & -- \\
\hline $\mathrm{La}$ & 25 & --- & --- & --- \\
\hline $\mathrm{Ce}$ & 69 & --- & --- & -- \\
\hline $\mathrm{Nd}$ & 27 & --- & -- & -- \\
\hline $\mathrm{Sm}$ & 5 & --- & -- & --- \\
\hline $\mathrm{Yb}$ & 4 & -- & --- & -- \\
\hline $\mathrm{Hf}$ & 2 & --- & --- & -- \\
\hline $\mathrm{Ta}$ & 1 & -- & --- & -- \\
\hline $\mathrm{Pb}$ & 10 & --- & --- & --- \\
\hline Th & 9 & --- & --- & --- \\
\hline $\mathrm{U}$ & 1 & --- & --- & --- \\
\hline
\end{tabular}

Analyses A and B are simplified compositions used for the calculation of pseudosections.

occur in the P-T frame of the pseudosection (Fig. 7). The same is true for compositions of garnet in GC04-27b (Fig. 8). Furthermore, the observed modal composition of GC04-27b can be close to those calculated (Table 4).

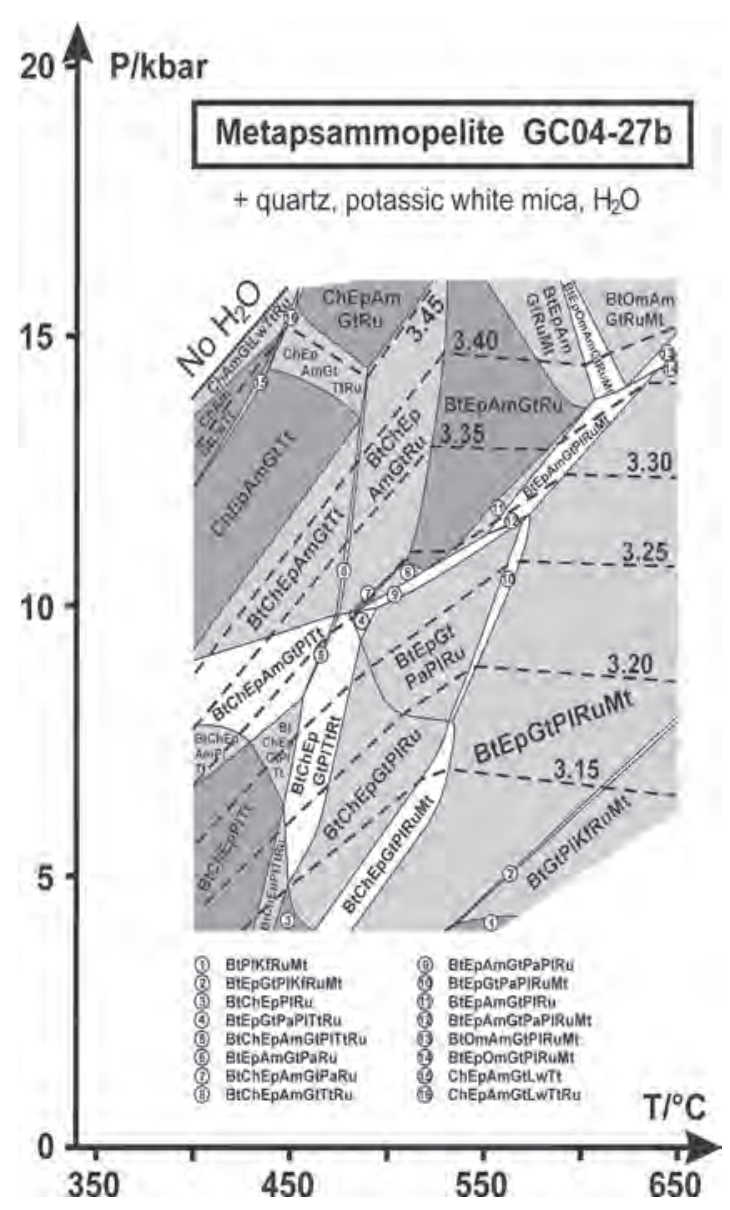

FIG. 7. P-T pseudosection for sample GC04-27b (composition A of Table 3). White, light grey and dark grey fields refer to 10,9 , and 8 , respectively, coexisting phases. A few tiny P-T fields are not labelled. Abbreviations: $\mathbf{A m}=$ amphibole; Bt=biotite; $\mathbf{C h}=$ chlorite; $\mathbf{E p}=$ epidote; $\mathbf{G t}=$ garnet; $\mathbf{K f}=\mathrm{K}$-feldspar; $\mathbf{L w}=$ lawsonite; $\mathbf{M t}=$ magnetite; $\mathbf{O m}=$ omphacite; $\mathbf{P a}=$ paragonite; $\mathbf{P l}=$ plagioclase; $\mathbf{R u}=$ rutile; $\mathbf{T t}=$ titanite. Isopleths for the $\mathrm{Si}$ content $\mathrm{pfu}$ in potassic white mica are shown by thick broken lines.

As $\mathrm{H}_{2} \mathrm{O}$ was not necessarily present in GC04$27 \mathrm{~b}$ during the entire metamorphic evolution, we have calculated also a P-T pseudosection for GC04$27 \mathrm{~b}$ with significantly less $\mathrm{H}_{2} \mathrm{O}$ (composition $\mathrm{B}$ of Table 3) than in composition $\mathrm{A}$ in order to find out what could be the effect of a water deficit. This pseudosection was simplified by displaying just the limits of the occurrences of specific minerals in figure 9. For instance, the P-T fields of the hydrous phases epidote and chlorite were significantly diminished by the lowering of the $\mathrm{H}_{2} \mathrm{O}$ content in GC04-27b whereas the lower pressure limit of the occurrence of amphibole did hardly change. 


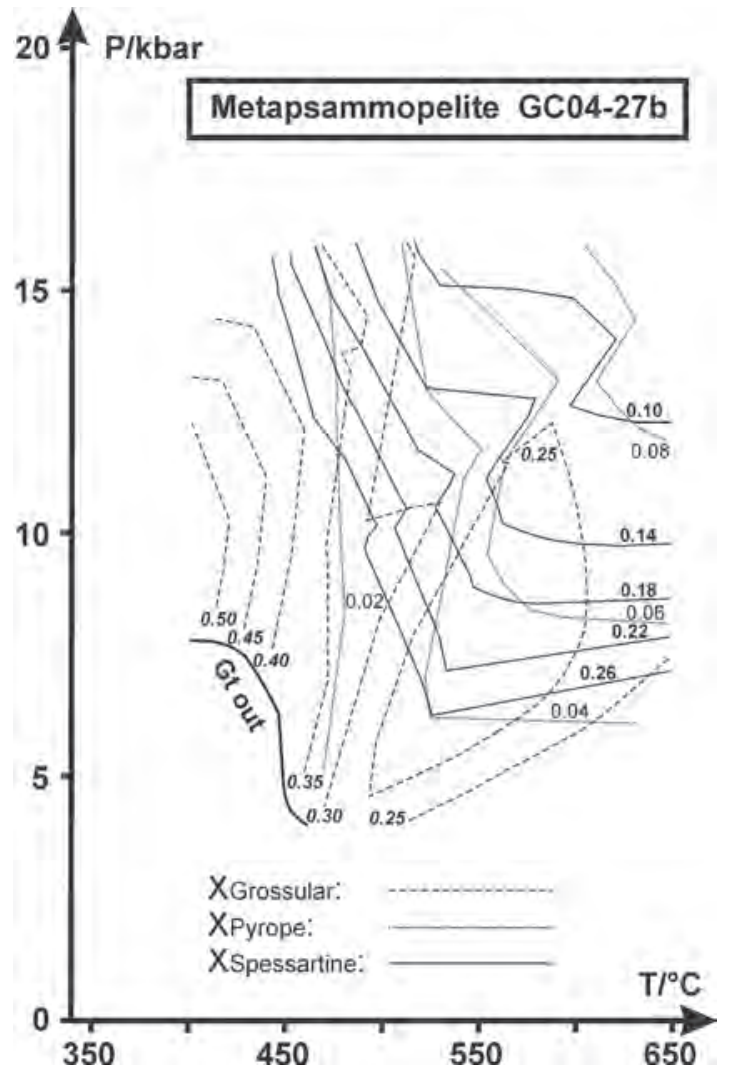

FIG. 8. Isopleths for molar fractions of garnet components related to the pseudosection of figure 7. An isopleth for Xspessartine $=0.30$ is lacking because the garnet composition was limited to $30 \mathrm{~mol} \%$ spessartine (see text).

In addition, the P-T positions of the isopleths for $\mathrm{Si}$ in potassic white mica and molar fractions of garnet components can be significantly shifted by this lowering compared to those in figures 7 and 8 especially at temperatures below $500^{\circ} \mathrm{C}$.

As the P-T curves for the selected equilibria E1 to E7, calculated with PTGIBBS, are virtually straight lines, we have presented only two P-T data for each curve in table 5 for a relevant $\mathrm{P}$ or $\mathrm{T}$ range. Considering the moderate scatter of the various curves for metamorphic stage II, the corresponding $\mathrm{P}-\mathrm{T}$ conditions could have been close to $12.5 \mathrm{kbar}$ and $550^{\circ} \mathrm{C}$ (Fig. 10). For this estimate, we have taken into account that the temperature obtained from the garnet-phengite pair (E6) is less precise than that obtained from the garnet-biotite pair (E5). The P-T estimate for stage I is located at somewhat higher pressures but lower temperatures compared to stage II (Fig. 10). The P-T conditions of stage

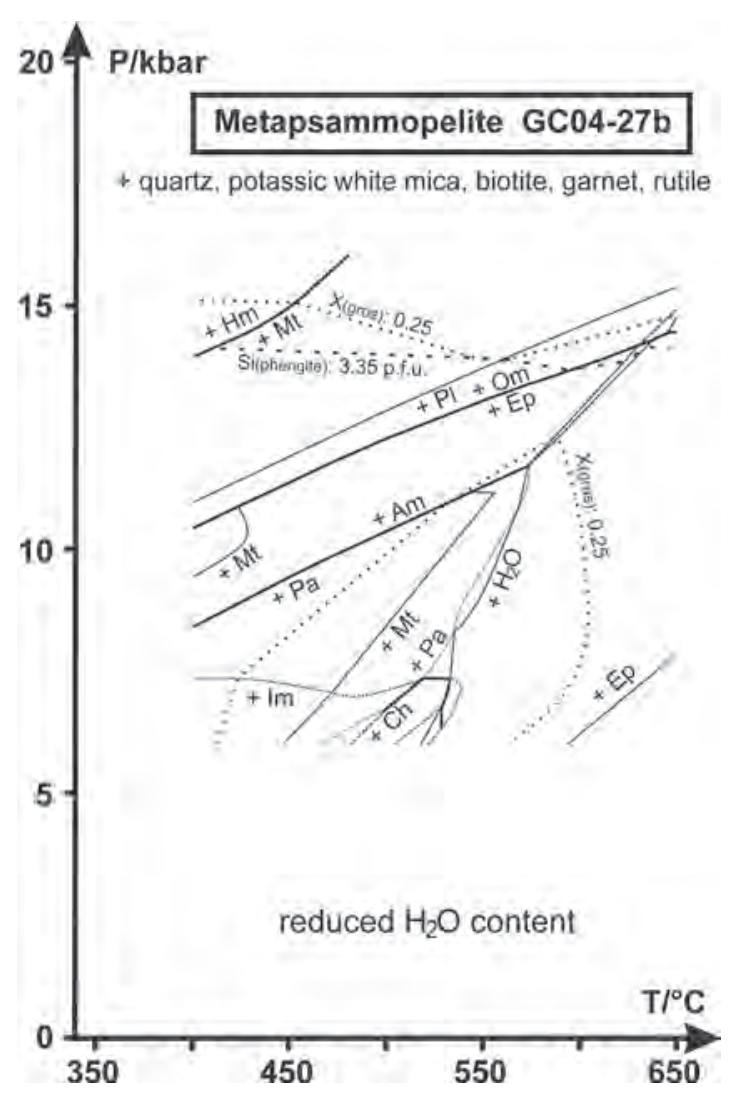

FIG. 9. Simplified pseudosection for sample GC04-27b with less water (composition B of Table 3). Only limits of mineral phases and $\mathrm{H}_{2} \mathrm{O}$ are shown. In addition, one $\mathrm{Si}$ isopleth for phengite and the isopleth for $25 \mathrm{~mol} \%$ grossular component in garnet are displayed. Abbreviations as in figure 7. $\mathbf{H m}=$ hematite; $\mathbf{I m}=$ ilmenite.

III were estimated to be close to $8 \mathrm{kbar}$ and $550^{\circ} \mathrm{C}$ being compatible with the maximum P-T conditions given by Ruviños et al. (1997) for the Guarguaraz Complex.

\section{Discussion and conclusions}

\subsection{P-T path}

To reconstruct a P-T path for the Guarguaraz Complex we have combined the results of both thermodynamic methods outlined in the previous section. The pseudosection turned out to be more useful than the calculation of mineral equilibria to decipher the P-T conditions of the early metamorphic evolution since the assumption is problematic that core compositions of biotite, 
TABLE 4. MODAL COMPOSITION (VOL\%) AND CHEMICAL CHARACTERISTICS OF SOLID-SOLUTION SERIES IN ROCK COMPOSITION A OF TABLE 3 AT SELECTED P-T CONDITIONS CALCULATED WITH PERPLE_X.

\begin{tabular}{|c|c|c|c|c|}
\hline $\mathbf{T}$ & $470^{\circ} \mathrm{C}$ & $520^{\circ} \mathrm{C}$ & $560^{\circ} \mathrm{C}$ & $560^{\circ} \mathrm{C}$ \\
\hline $\mathbf{P}$ & 8 kbar & 13.5 kbar & 11.5 kbar & $7.5 \mathrm{kbar}$ \\
\hline Quartz & 46.55 & 44.68 & 46.02 & 47.35 \\
\hline Rutile & 0.24 & 0.39 & 0.38 & 0.37 \\
\hline Titanite & 0.41 & -- & -- & -- \\
\hline $\mathrm{K}$ white mica & 27.10 & 32.76 & 28.39 & 21.38 \\
\hline Biotite & 10.77 & 4.43 & 9.68 & 15.60 \\
\hline Chlorite & 3.26 & 0.61 & -- & -- \\
\hline Plagioclase & 5.44 & -- & 2.80 & 8.10 \\
\hline Amphibole & --- & 9.39 & 4.47 & --- \\
\hline Epidote & 3.41 & 2.20 & 2.62 & 2.31 \\
\hline Garnet & 0.62 & 3.02 & 2.65 & 1.15 \\
\hline Magnetite & -- & -- & 0.01 & 0.07 \\
\hline $\mathrm{H}_{2} \mathrm{O}$ & 2.22 & 2.52 & 2.98 & 3.66 \\
\hline $\mathrm{H}_{2} \mathrm{O}$ in wt $\%$ & 0.80 & 0.96 & 1.10 & 1.26 \\
\hline (Si pfu) phengite & 3.25 & 3.38 & 3.29 & 3.15 \\
\hline (XMg) phengite & 0.50 & 0.53 & 0.50 & 0.46 \\
\hline (Na pfu) phengite & 0.08 & 0.04 & 0.08 & 0.06 \\
\hline (Si pfu) biotite & 2.98 & 2.98 & 2.95 & 2.85 \\
\hline (XMg) biotite & 0.44 & 0.50 & 0.50 & 0.47 \\
\hline (Si pfu) chlorite & 2.98 & 2.97 & -- & --- \\
\hline (XMg) chlorite & 0.43 & 0.47 & -- & --- \\
\hline (Si pfu) amphibole & -- & 7.69 & 7.52 & --- \\
\hline (XMg) amphibole. & -- & 0.50 & 0.48 & --- \\
\hline (Na pfu) amphibole & -- & 1.73 & 1.56 & --- \\
\hline (Ca pfu) amphibole & -- & 0.31 & 0.48 & --- \\
\hline$(\mathrm{XMg})$ garnet & 0.01 & 0.04 & 0.05 & 0.05 \\
\hline (XCa) garnet & 0.35 & 0.27 & 0.25 & 0.22 \\
\hline$(\mathrm{XMn})$ garnet & 0.25 & 0.09 & 0.10 & 0.14 \\
\hline (Xalbite) plagioclase & 1.00 & -- & 1.00 & 0.74 \\
\hline$\left(\mathrm{Fe}^{3+} \mathrm{pfu}\right)$ epidote & 0.56 & 0.72 & 0.72 & 0.64 \\
\hline
\end{tabular}

phengite, and garnet represent an equilibrium assemblage. Nevertheless, the information from the pseudosection alone is at the first glance also conflicting for the earliest stage Ia, because the inner core of garnet should have formed at about $8 \mathrm{kbar}$ and temperatures of $500^{\circ} \mathrm{C}$ or somewhat above (see circle in figure 10) and, thus, outside the $\mathrm{P}-\mathrm{T}$ field of titanite which is enclosed in the garnet

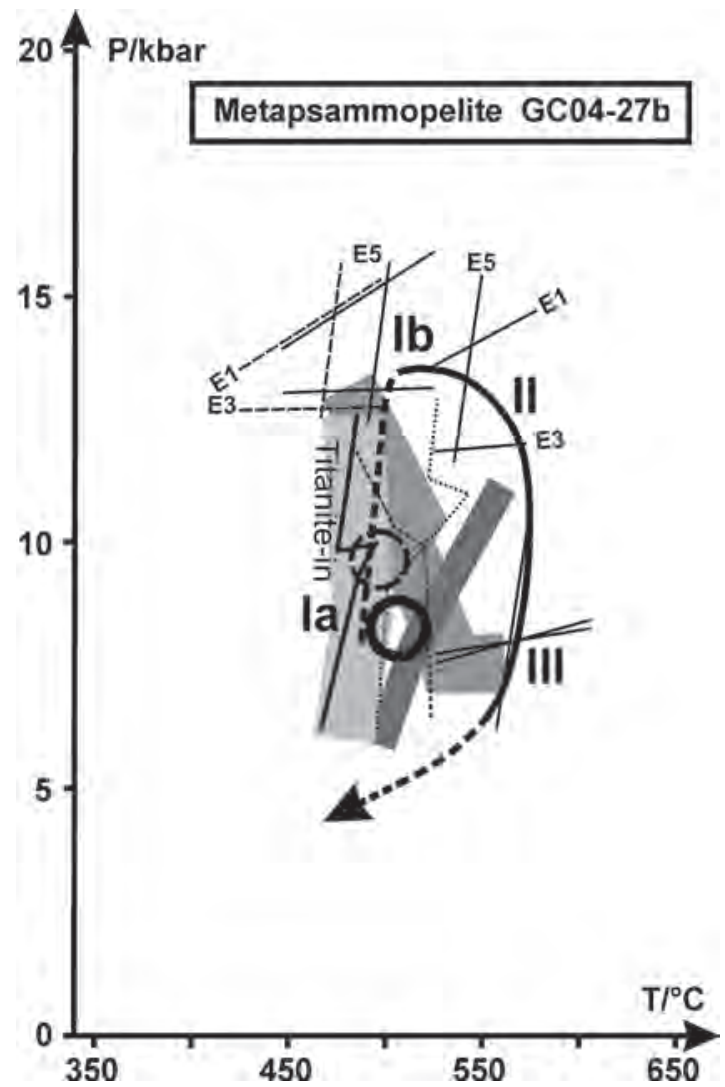

FIG. 10. Pressure versus temperature diagram showing the derived P-T path (thick line-solid portion is well constrained by investigating sample GC04-27b) for the Guaguaraz Complex. Early metamorphic stage Ia is characterized by the presence of titanite (see Fig. 7) and the composition of the inner core of garnet (see analysis 7-5 of Table 1). The circle defines the most likely P-T conditions for the existence of such a garnet composition according to figure 8. A CaO content of composition A (Table 3 ) reduced to one half $(0.63 \mathrm{wt} \%)$ causes a shift of the isopleths for garnet components (dotted line: $\mathrm{X}_{\text {Grossular }}=0.251$, short dashed line: $X_{\text {Spessartine }}=0.216$ ). The broken circle marks the corresponding shift of the solid circle. For stages Ib, II (garnet rim) and III (outermost garnet rim+rock matrix) the calculated P-T position of selected equilibria (see Table 5) are exhibited (long dashed lines for stage Ia). The solid P-T path is also compatible with phase relations shown in the pseudosection of figure 7.

core. However, we have to consider that titanite, which is a pure phase in the calculation of the P-T pseudosection for composition $\mathrm{A}$, is stabilized to higher temperatures by the introduction of $\mathrm{Al}+\mathrm{Fe}^{3+}$ $\left(\right.$ probably $+\mathrm{H}^{+}$) for $\mathrm{Ti}^{4+}$ (Table 2). Moreover, some $\mathrm{Ca}$ is also in apatite resulting in a Ca content of the bulk composition for the pseudosection lower than taken into account. We have proven by calculating 
TABLE 5. P-T CONDITIONS DERIVED FOR METAPELITE GC04-27B ON THE BASIS OF MINERAL EQUILIBRIA (E1)-E(6). (E7) WAS CALCULATED FOR DIFFERENT WATER ACTIVITY $\left(\mathrm{aH}_{2} \mathrm{O}\right)$.

\begin{tabular}{|c|c|c|c|c|c|c|c|c|}
\hline \multirow[t]{2}{*}{ Stage } & \multirow[t]{2}{*}{ Equilibrium } & \multirow[t]{2}{*}{ Mineral analyses } & \multirow[t]{2}{*}{$\mathrm{aH}_{2} \mathrm{O}$} & \multicolumn{5}{|c|}{ Calculated pressure or temperature } \\
\hline & & & & $425^{\circ} \mathrm{C}$ & $525^{\circ} \mathrm{C}$ & $625^{\circ} \mathrm{C}$ & 10 kbar & 20 kbar \\
\hline \multirow[t]{9}{*}{ Ia } & (E1) & garnet $7-5$ (core) & --- & $13.50 \mathrm{kbar}$ & $16.04 \mathrm{kbar}$ & -- & --- & -- \\
\hline & (E2) & phengite 5-41 (core) & -- & $14.42 \mathrm{kbar}$ & $15.09 \mathrm{kbar}$ & -- & -- & -- \\
\hline & (E3) & biotite $5-16$ (core) & -- & $12.70 \mathrm{kbar}$ & $12.78 \mathrm{kbar}$ & -- & -- & -- \\
\hline & (E4) & -- & --- & $8.55 \mathrm{kbar}$ & $11.55 \mathrm{kbar}$ & -- & -- & -- \\
\hline & (E5) & --- & --- & -- & -- & -- & $459^{\circ} \mathrm{C}$ & $492^{\circ} \mathrm{C}$ \\
\hline & (E5) $\mathrm{K} \& \mathrm{R}$ & -- & -- & -- & -- & -- & $434^{\circ} \mathrm{C}$ & $460^{\circ} \mathrm{C}$ \\
\hline & (E6) & -- & --- & -- & -- & -- & $393^{\circ} \mathrm{C}$ & $390^{\circ} \mathrm{C}$ \\
\hline & (E7) & -- & 1.0 & $11.48 \mathrm{kbar}$ & $14.32 \mathrm{kbar}$ & -- & -- & -- \\
\hline & -- & --- & 0.5 & $13.20 \mathrm{kbar}$ & $16.32 \mathrm{kbar}$ & -- & -- & -- \\
\hline \multirow[t]{7}{*}{$\mathrm{Ib}$} & (E1) & garnet 7-20 (intermediate) & --- & $13.39 \mathrm{kbar}$ & $15.92 \mathrm{kbar}$ & -- & -- & -- \\
\hline & (E2) & phengite 5-41 (core) & --- & $14.76 \mathrm{kbar}$ & $15.49 \mathrm{kbar}$ & -- & -- & -- \\
\hline & (E3) & biotite $5-16$ (core) & --- & $13.01 \mathrm{kbar}$ & $13.14 \mathrm{kbar}$ & -- & -- & -- \\
\hline & (E4) & -- & --- & $9.19 \mathrm{kbar}$ & $12.28 \mathrm{kbar}$ & -- & -- & -- \\
\hline & (E5) & -- & --- & -- & -- & -- & $483^{\circ} \mathrm{C}$ & $517^{\circ} \mathrm{C}$ \\
\hline & (E5) $\mathrm{K} \& \mathrm{R}$ & -- & -- & -- & -- & -- & $454^{\circ} \mathrm{C}$ & $481^{\circ} \mathrm{C}$ \\
\hline & (E6) & -- & -- & -- & -- & -- & $410^{\circ} \mathrm{C}$ & $407^{\circ} \mathrm{C}$ \\
\hline \multirow[t]{16}{*}{ II } & (E1) & garnet 7-29 (rim) & --- & -- & $13.60 \mathrm{kbar}$ & $15.73 \mathrm{kbar}$ & -- & -- \\
\hline & (E2) & phengite 5-36 (incl. in Qz) & --- & -- & $13.94 \mathrm{kbar}$ & $14.32 \mathrm{kbar}$ & -- & -- \\
\hline & (E3) & biotite $5-16$ (core) & --- & -- & $11.85 \mathrm{kbar}$ & $12.18 \mathrm{kbar}$ & --- & -- \\
\hline & (E4) & --- & --- & -- & $13.80 \mathrm{kbar}$ & $17.17 \mathrm{kbar}$ & --- & -- \\
\hline & (E5) & -- & -- & -- & -- & -- & $530^{\circ} \mathrm{C}$ & $567^{\circ} \mathrm{C}$ \\
\hline & (E5) K\&R & -- & -- & -- & -- & -- & $491^{\circ} \mathrm{C}$ & $519^{\circ} \mathrm{C}$ \\
\hline & (E6) & -- & --- & -- & -- & --- & $426^{\circ} \mathrm{C}$ & $428^{\circ} \mathrm{C}$ \\
\hline & (E7) & --- & 1.0 & -- & $12.17 \mathrm{kbar}$ & $14.58 \mathrm{kbar}$ & -- & -- \\
\hline & -- & -- & 0.5 & -- & $14.18 \mathrm{kbar}$ & $16.88 \mathrm{kbar}$ & -- & -- \\
\hline & (E1) & garnet 7-29 (rim) & --- & -- & $14.18 \mathrm{kbar}$ & $16.39 \mathrm{kbar}$ & --- & -- \\
\hline & (E2) & phengite 5-36 (incl. in Qz) & --- & -- & $14.26 \mathrm{kbar}$ & $14.67 \mathrm{kbar}$ & -- & -- \\
\hline & (E3) & biotite $5-27$ & -- & -- & $12.43 \mathrm{kbar}$ & $12.82 \mathrm{kbar}$ & -- & -- \\
\hline & (E4) & -- & --- & -- & $13.80 \mathrm{kbar}$ & $17.17 \mathrm{kbar}$ & -- & -- \\
\hline & (E5) & -- & --- & -- & -- & -- & $513^{\circ} \mathrm{C}$ & $550^{\circ} \mathrm{C}$ \\
\hline & (E5) $K \& R$ & --- & --- & --- & -- & -- & $482^{\circ} \mathrm{C}$ & $509^{\circ} \mathrm{C}$ \\
\hline & (E6) & -- & -- & -- & -- & -- & $426^{\circ} \mathrm{C}$ & $428^{\circ} \mathrm{C}$ \\
\hline \multirow[t]{9}{*}{ III } & (E1) & garnet 7-30 (outerm. rim) & --- & -- & $7.52 \mathrm{kbar}$ & $8.64 \mathrm{kbar}$ & -- & -- \\
\hline & (E2) & phengite 5-57 (rim) & -- & -- & $8.15 \mathrm{kbar}$ & $7.63 \mathrm{kbar}$ & -- & -- \\
\hline & (E3) & biotite $5-27$ & --- & -- & $7.73 \mathrm{kbar}$ & $8.37 \mathrm{kbar}$ & -- & -- \\
\hline & (E4) & -- & -- & -- & $17.00 \mathrm{kbar}$ & $20.85 \mathrm{kbar}$ & -- & -- \\
\hline & (E5) & -- & --- & -- & -- & -- & $572^{\circ} \mathrm{C}$ & $611^{\circ} \mathrm{C}$ \\
\hline & (E5) K\&R & -- & -- & -- & -- & -- & $490^{\circ} \mathrm{C}$ & $520^{\circ} \mathrm{C}$ \\
\hline & (E6) & --- & -- & -- & -- & -- & $574^{\circ} \mathrm{C}$ & $648^{\circ} \mathrm{C}$ \\
\hline & (E7) & -- & 1.0 & -- & $6.28 \mathrm{kbar}$ & $7.80 \mathrm{kbar}$ & -- & -- \\
\hline & -- & --- & 0.5 & -- & 8.14 kbar & $9.91 \mathrm{kbar}$ & -- & - \\
\hline
\end{tabular}


a pseudosection for composition A with only 0.63 wt $\%$ instead of $1.26 \mathrm{wt} \% \mathrm{CaO}$ that the $\mathrm{X}_{\text {Grossular }}$ isopleth in figure 10 (thick dark-grey line) shifts towards lower temperatures at reduced contents of $\mathrm{CaO}$ in the bulk rock. Thus, the temperature of stage Ia could be somewhat below $500^{\circ} \mathrm{C}$. As the $\mathrm{X}_{\text {Spessartine }}$ and $\mathrm{X}_{\text {Pyrope }}$ isopleths show a shift similar to the $X_{\text {Grossular }}$ isopleth, the estimated pressure for stage Ia would be higher (see broken circle in figure 10) than 8 kbar (obtained using the composition of the inner core of garnet and the pseudosection for bulk composition A, figure 8).

The early portion of the reconstructed P-T path of figure 10 , starting possibly at $485^{\circ} \mathrm{C}$ and $8 \mathrm{kbar}$, is characterized by temperature increase causing the growth of zoned garnets with a so-called 'bell-shaped' Mn-curve (=compositional section from rim to rim through the core of garnet). Such curves are indeed typical for continuous garnet growth during a prograde metamorphic evolution (Hollister, 1966). However, only a slight rise of the temperature could be derived for a burial event at the beginning of the recorded metamorphic evolution to reach conditions of about $500^{\circ} \mathrm{C}$ and $13.5 \mathrm{kbar}$ (stage Ib). These P-T conditions are compatible with the composition of phengite cores (Si almost 3.40 pfu, Fig. 7) and an intermediate garnet composition (Table 1, Fig. 5) with slightly higher $\mathrm{Mg}$, nearly the same $\mathrm{Ca}$ and significantly lower Mn contents compared to the inner core of garnet (Fig. 8). The calculations of equilibria with corresponding phengite and garnet compositions yielded also pressures around $13.5 \mathrm{kbar}$ (Table 5) but temperatures somewhat lower than $500^{\circ} \mathrm{C}$. Possibly, the composition of biotite used for these calculations was not in equilibrium with the phengite core. In principle, however, biotite should have been part of the Ib mineral assemblage independent of the presence of water (i.e., water activity close to unity) or absence of water (i.e., water-deficient conditions) as shown in figures 7 and 9. Chlorite, however, which was found enclosed in the intermediate garnet zone, should only occur at $13.5 \mathrm{kbar}$ and $500^{\circ} \mathrm{C}$ in the presence of water (Fig. 7). The presence of amphibole and absence of plagioclase is another feature of the mineral assemblage of stage $\mathrm{Ib}$ independent of the presence or absence of water (compare Figs. 7 and 9). Amphibole was, indeed, observed as relic in lately grown plagioclase, although the composition of amphibole is tschermakitic (Table 2) in contrast to
Na-rich amphibole appearing in the pseudosections (Table 4).

After heating and slight pressure release the garnet rim of stage II and phengite with Si contents somewhat above 3.3 pfu seem to have been in equilibrium. The P-T conditions of this stage are estimated to be about $550^{\circ} \mathrm{C}$ and $12.5 \mathrm{kbar}$ considering the calculated equilibria (Table 5), the mineral assemblage of the pseudosection (Fig. 7) before plagioclase growth and the garnet isopleths of figure 8 . The latter would point to somewhat higher temperatures according to the spessartine content of only $10 \mathrm{~mol} \%$ in the garnet rim. However, a considerable amount of $\mathrm{Mn}$ was already fixed in the garnet core and, thus, could not take part in the mineral reactions anymore. This led to a spessartine content in the garnet rim lower than calculated for the above P-T conditions.

With further rising temperature but mainly with falling pressures plagioclase grew after stage II to form large blasts at the expense of amphibole (only very few corroded relics in plagioclase witness this event). This reaction releases water so that towards stage III it is likely that water was present enhancing the equilibration of matrix phases. In contrast, deformation did not play any role for equilibration at the matrix stage III according to undeformed plagioclase blasts as well as lacking lately deformed micas and pressure shadows around garnet and plagioclase blasts. Deformation, however, must have occurred at and/or between stages I and II resulting in variably oriented mica flakes. The P-T conditions of the growth of plagioclase can further be corroborated by the fact that plagioclase is nearly pure albite (see calculation result for $560^{\circ} \mathrm{C}$ and $11.5 \mathrm{kbar}$ in Table 4) and that phengite with $\mathrm{Si} \geq 3.30$ pfu (see $\mathrm{Si}$ isopleths in figure 7) is enclosed in plagioclase. Rare chlorite and titanite inclusions in the plagioclase blasts were probably first enclosed in amphibole before its digestion because these inclusion minerals had already disappeared from the equilibrium assemblage before plagioclase growth according to the calculated pseudosection of figure 7 and the derived P-T path of figure 10 .

A final equilibration stage III could be well defined by the compositions of the outermost rim of garnet and the rims of micas in the rock matrix. Results of both calculation of equilibria (Table 5) and computation of a pseudosection point to P-T conditions close to $8 \mathrm{kbar}$ and $565^{\circ} \mathrm{C}$. At these 
conditions, the Si contents of potassic white mica, coexisting with biotite, epidote, garnet, plagioclase, quartz, rutile and magnetite, should be below 3.20 pfu and the spessartine and grossular contents of garnet should be higher and lower, respectively, compared to garnet equilibrated at stage II according to the pseudosection (Figs. 7 and 8 and Table 4). These features were, indeed, observed (Table 1) except the presence of magnetite. However, the calculated contents of magnetite are very small. Moreover, some $\mathrm{Fe}^{3+}$ is also in garnet and micas, which is ignored in the applied solid-solution models, resulting in a reduction of the magnetite content. The here derived pressure conditions for stage III are compatible with the P-T estimate by Ruviños et al. (1997) who reported $9 \pm 2$ kbar and $500 \pm 50^{\circ} \mathrm{C}$. However, our temperature for stage III is higher than the temperature estimated by these authors on the basis of garnet-hornblende thermometry applied to basic lithologies. More importantly, Ruviños et al. (1997) regarded their P$\mathrm{T}$ conditions as peak conditions for the Guarguaraz Complex which we could disprove in this work. Possibly due to stronger overprint, the investigated basic rocks were not so suitable as Ca-poorer metapelites (sample GC04-27b) to decipher the early metamorphic evolution.

After stage III, only minor mineralogical changes occurred in sample GC04-27b. We think that the partial transformation of rutile to ilmenite and the appearance of small chlorite grains at biotite rims are among these changes. Nevertheless, these alterations did not allow us to reconstruct the P-T conditions for a post stage III event. Ruviños et al. (1997), however, found indications for a retrograde path from about $9 \mathrm{kbar}$ and $500^{\circ} \mathrm{C}$ to $325^{\circ} \mathrm{C}$ and 6 kbar for the Guarguaraz Complex.

\subsection{Geodynamic consequences}

Early P-T conditions (stage $\mathrm{Ib}$ ) of $500^{\circ} \mathrm{C}$ and $13.5 \mathrm{kbar}$ ( $\sim 45 \mathrm{~km}$ depth) can be related to a geotherm somewhat above $10^{\circ} \mathrm{C} / \mathrm{km}$. Such a low geotherm would be compatible with a subduction zone environment and, thus, with the idea of an accretionary complex (López and Gregori, 2004). However, compared to the rocks from the younger accretionary complexes of the Chilean Coastal Cordillera (Fig. 11) the investigated rocks of the Guarguaraz Complex have experienced higher P-T conditions and would, thus, represent a very deep portion of an accretionary wedge. In fact, such rocks very rarely occur in the Chilean Coastal Cordillera but they show a different P-T evolution. Willner et al. (2004b) reported a metabasic rock which recorded even a counterclockwise P-T path characterized by (nearly isobaric) cooling to 10.5 $14 \mathrm{kbar}$ and $350-500^{\circ} \mathrm{C}$.

Alternatively, the high-pressure conditions could have been attained during an event in Devonian times when continental plates collided (Davis et al., 1999). These plates were Gondwana (Cuyania, previously amalgamated to the western Gondwana margin - see Ramos, 2004) or Chilenia (see Ramos et al., 1998), of which the Guarguaraz Complex is assumed to be part of (López and Gregori, 2004). In fact, Davis et al. (1999) preferred thrusting of Gondwana under Chilenia but it should be the opposite when the Guarguaraz Complex would be part of Chilenia. Gerbi et al. (2002) investigated rocks of the Precordillera terrane (part of Cuyania) north of the Guarguaraz Complex and also argued for a west-dipping subduction zone in the Middle Devonian. Nevertheless, in both cases (polarity of subduction) thickening of orogenic crust should occur (Fig. 12). Although our estimate of the P-T conditions for stage Ia (close to $8 \mathrm{kbar}, 485^{\circ} \mathrm{C}$ ) is not precise, these conditions support rather the idea of crustal thickening because of a deducible geotherm above $15^{\circ} \mathrm{C} / \mathrm{km}$ for this stage. Moreover, the subsequent significant pressure increase combined with slight temperature rise (stage Ia to $\mathrm{Ib}$ ) followed by thermal relaxation (stage II) is typical for such a geodynamic situation. During this collisional event, the Guarguaraz Complex, which was part of a continental margin (see López et al., 1999) and, therefore, could have also been a former accretionary wedge complex, was deeply buried. The exhumation after stage II was probably caused by (fast?) surface erosion (of a mountain chain?) resulting in a nearly isothermal pressure release of the Guarguaraz Complex without any significant deformation.

Further exhumation of the Guarguaraz Complex from depths of about $30 \mathrm{~km}$ is not recorded in the selected sample as it well preserves the highpressure event and shows only a moderate overprint at medium-pressure conditions. This could be a further indication for a simple erosional process at least in regard of exhumation of the Guarguaraz Complex from the $30 \mathrm{~km}$ depth level (before later Andean tectonics). Altogether, we conclude that 


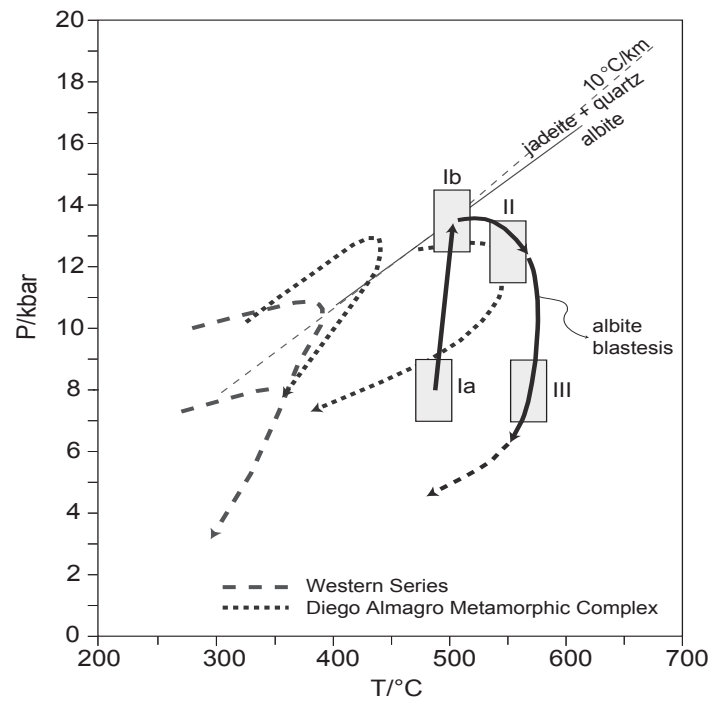

FIG. 11. Pressure versus temperature diagram showing derived $\mathrm{P}-\mathrm{T}$ conditions and the estimated P-T path for metapelites of the Guaguaraz Complex. Boxes indicate assumed errors for the P-T conditions of the different metamorphic stages Ia to III. P-T trajectories for the Western Series in the Late Paleozoic paired metamorphic belts in north-central Chile and for the Late Mesozoic Diego Almagro Metamorphic Complex in southern Chile are from Willner et al. (2005) and Willner et al. (2004a), respectively, for comparison.

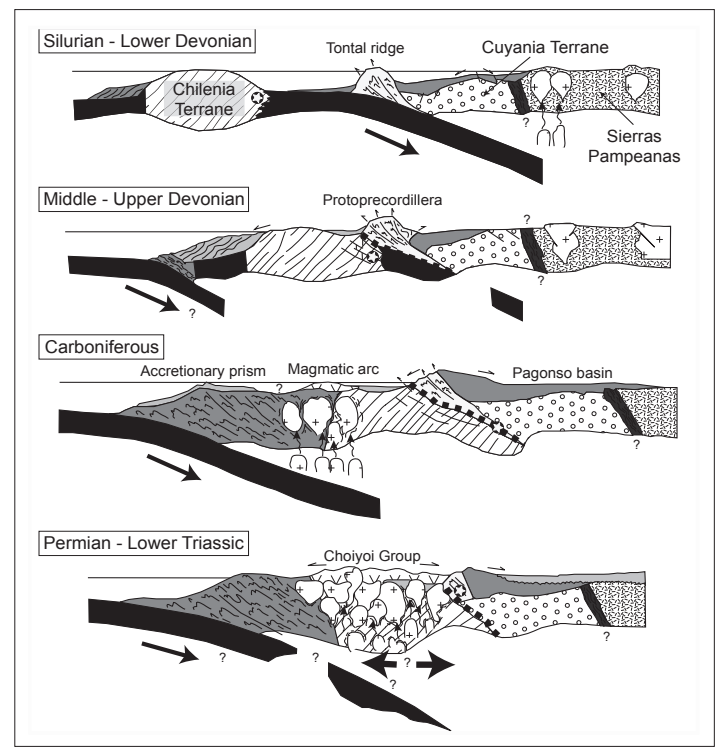

FIG. 12. Possible geodynamic scenario (W-E profiles) for the western Gondwana margin (Fig. 1a) from Silurian to Triassic times modified after Mpodozis and Ramos (1990) to account for the derived P-T path of figure 10. White star in black circle marks the assumed position of the Guarguaraz Complex. the clockwise P-T loop of figure 10 is consistent with a continent-continent collisional scenario (Fig. 12). A similar event could have occurred already in Famatinian times when Grenvillian basement (Cuyania) was accreted to Gondwanan South America (Casquet et al., 2001; Ramos, 2004) resulting also in high-pressure metamorphism in the Sierra de Pie de Palo.

If the here deduced geotectonic scenario (Fig. 12) is correct, it means that collision of a continental plate with another but small continental plate (microplate such as Chilenia) even results in a considerable thickening of continental crust. The common believe is that such kind of collision is more or less a simple docking (or accretion) of a microplate to a larger continental plate, which would, thus, be only discernable by (near-) surface processes, such as the development of a basin between the colliding plates including changes of fauna, or by palaeomagnetic constraints. Corresponding arguments are still important but the investigations of metamorphic P-T paths are essential to understand the true geodynamic situation.

\section{Acknowledgements}

The stay of HJM in South America was financially supported by a BMBF-CONICYT program (CHL 02/012). Reviews by A. García Casco, D. Gregori, G. Vujovich, A. Willner and an anonymous reviewer helped to improve this manuscript.

\section{References}

Basei, M.; Ramos, V.A.; Vujovich, G.I.; Poma, S. 1998. El basamento metamórfico de la Cordillera Frontal de Mendoza: nuevos datos geocronólogicos e isotópicos. In Congreso Latinoamericano de Geología, No. 10 y Congreso Nacional de Geología Económica, No. 6, Actas 2: 412-417. Buenos Aires.

Berman, R.G. 1988. Internally-consistent thermodynamic data for minerals in the system $\mathrm{Na}_{2} \mathrm{O}-\mathrm{K}_{2} \mathrm{O}-\mathrm{CaO}-\mathrm{MgO}-$ $\mathrm{FeO}-\mathrm{Fe}_{2} \mathrm{O}_{3}-\mathrm{Al}_{2} \mathrm{O}_{3}-\mathrm{SiO}_{2}-\mathrm{TiO}_{2}-\mathrm{H}_{2} \mathrm{O}-\mathrm{CO}_{2}$. Journal of Petrology 29: 445-522.

Bernhardt, H.J.; Massonne, H.-J.; Reinecke, T.; Reinhardt, J.; Willner, A. 1995. Digital element distribution maps, an aid for petrological investigations. Berichte der Deutschen Mineralogischen Gesellschaft, Beihefte zum European Journal of Mineralogy 7 (1): p. 28.

Brandelik, A.; Massonne, H.-J. 2004. PTGIBBS-an EXCEL $^{\mathrm{TM}}$ Visual Basic program for computing and visualizing thermodynamic functions and equilibria of rock-forming minerals. Computers and Geosciences 30: 909-923.

Casquet, C.; Baldo, E.; Pankhurst, R.J.; Rapela, C.W.; Galindo, C.; Fanning, C.M.; Saavedra, J. 2001. 
Involvement of the Argentine Precordillera terrane in the Famatinian mobile belt: U-Pb SHRIMP and metamorphic evidence from the Sierra de Pie de Palo. Geology 29: 703-706.

Connolly, J.A.D. 1990. Multivariable phase diagrams; an algorithm based on generalized thermodynamics. American Journal of Science 290: 666-718.

Connolly, J.A.D. 2005. Computation of phase equilibria by linear programming: A tool for geodynamic modeling and its application to subduction zone decarbonation. Earth and Planetary Science Letters 236: 524-541.

Davis, J.; Roeske, S.; McClelland, W.; Snee, L. 1999. Closing the ocean between the Precordillera terrane and Chilenia: Early Devonian ophiolite emplacement and deformation in the southwest Precordillera. In Laurentia and Gondwana Connections before Pangea (Ramos, V.; Keppie, J.; editors). Geological Society of America, Special Papers 336: 115-138.

Gerbi, C.; Roeske, S.M.; Davis, J.S. 2002. Geology and structural history of the southwest Precordillera margin, northern Mendoza Province, Argentina. Journal of South American Earth Sciences 14: 821-835.

Gregori, D.A.; Bjerg, E.A. 1992. Los depósitos de talco del distrito minero Salamanca, Provincia de Mendoza. Revista de la Asociación Geológica Argentina 47: 55-59.

Gregori, D.A.; Ruviños, M.A.; Bjerg, E.A. 1997. Las metamorfitas del basamento de la Cordillera Frontal, entre el Río de las Tunas y el Ao. Barraquero, Provincia de Mendoza. In Congreso Geológico Chileno, No. 8, Actas 2: 1295-1299. Antofagasta.

Hervé, F. 1988. Late Paleozoic subduction and accretion in Southern Chile. Episodes 11: 183-188.

Holland, T.J.B.; Powell, R. 1998. An internally consistent thermodynamic data set for phases of petrological interest. Journal of Metamorphic Geology 16: 309-343.

Hollister, L.S. 1966. Garnet zoning: an interpretation based on the Rayleigh fractionation model. Science 154: 1647-1651.

Kleemann, U.; Reinhardt, J. 1994. Garnet-biotite thermometry revisited: The effect of $\mathrm{Al}^{\mathrm{VI}}$ and $\mathrm{Ti}$ in biotite. European Journal of Mineralogy 6: 925-941.

Leake, B.E.; Woolley, A.R.; Arps, C.E.S.; Birch, W.D.; Gilbert, M.C.; Grice, J.D.; Hawthorne, C.; Kato, A.; Kisch, H.J.; Krivovichev, V.G.; Linthout, K.; Laird, J.; Mandarino, J.A.; Maresch, W.V.; Nickel, E.H.; Rock, N.M.S.; Schumacher, J.C.; Smith, D.C.; Stephenson, C.N.; Ungaretti, L.; Whittaker, E.J.W.; Youzhi, G. 1997. Nomenclature of amphiboles: report of the subcommittee on amphiboles of the international mineralogical association, commission on new minerals and mineral names. The Canadian Mineralogist 35: 219-246.
López, V.; Gregori, D.A.; Migueles, N.A.; Di Martino, C. 1999. Nuevas facies en el basamento metamórfico de la Cordillera Frontal de Mendoza. In Congreso Geológico Argentino, No. 14, Actas 1: 141-144. Salta.

López, V.; Gregori, D.A. 2004. Provenance and evolution of the Guarguaraz Complex, Cordillera Frontal, Argentina. Gondwana Research 7: 1197-1208.

Massonne, H.-J. 1995. Is the concept of 'in situ' metamorphism applicable to deeply buried continental crust with lenses of eclogites and garnet peridotites? Chinese Science Bulletin 40, Supplement: 145-147.

Massonne, H.-J.; Hervé, F.; Muñoz, V.; Willner, A.P. 1996. New petrological results on high-pressure, lowtemperature metamorphism of the Upper Palaeozoic basement of Central Chile. In Symposium International sur la Géodynamique Andine, No. 3: 783-785. SaintMalo, France.

Massonne, H.-J.; Szpurka, Z. 1997. Thermodynamic properties of white micas on the basis of high-pressure experiments in the systems $\mathrm{K}_{2} \mathrm{O}-\mathrm{MgO}-\mathrm{Al}_{2} \mathrm{O}_{3}-\mathrm{SiO}_{2}-$ $\mathrm{H}_{2} \mathrm{O}$ and $\mathrm{K}_{2} \mathrm{O}-\mathrm{FeO}-\mathrm{Al}_{2} \mathrm{O}_{3}-\mathrm{SiO}_{2}-\mathrm{H}_{2} \mathrm{O}$. Lithos 41 : 229-250.

Mpodozis, C.; Ramos, V.A. 1990. The Andes of Chile and Argentina. In Geology of the Andes and its relation to hydrocarbon and mineral resources (Ericksen, G.E.; Cañas Pinochet, M.T.; Reinemund, J.A.; editors). Circum-Pacific Council for Energy and Mineral Resources, Earth Science Series 11: 59-90.

Powell, R.; Holland, T. 1999. Relating formulations of the thermodynamics of mineral solid solutions: Activity modeling of pyroxenes, amphiboles and micas. American Mineralogist 84: 1-14.

Ramos, V.A.; Jordan, T.; Allmendinger, R.; Kay, S.; Cortés, J.; Palma, M. 1984. Chilenia: un terreno alóctono en la evolución paleozoica de los Andes Centrales. In Congreso Geológico Argentino, No. 9, Actas 2: 84106. San Carlos de Bariloche.

Ramos, V.A.; Dallmeyer, D.; Vujovich, G.I. 1998. Ar/Ar constraints in the age of deformation of the Pie de Palo basement: Implications for the docking of Precordillera and Chilenia. In The Proto-Andean margin of Gondwana (Pankhurst, R.J.; Rapela, C.W.; editors). Geological Society of London, Special Publications 142: 143-158.

Ramos, V.A. 2004. Cuyania, an exotic block to Gondwana: review of a historical success and the present problems. Gondwana Research 7: 1009-1026.

Ruviños, M.A.; Gregori, D.A.; Bjerg, E.A. 1997. Condiciones de $\mathrm{P}$ y $\mathrm{T}$ del basamento metamórfico de la Cordillera Frontal de Mendoza, Argentina. In Congreso Geológico Chileno, No. 8, Actas 2: 1512-1516. Antofagasta.

Willner, A.P. 2005. Pressure-temperature evolution of a Late Palaeozoic paired metamorphic belt in NorthCentral Chile $\left(34^{\circ}-35^{\circ} 30^{\prime} \mathrm{S}\right)$. Journal of Petrology 46: 1805-1833. 
Willner, A.P.; Hervé, F.; Massonne, H.-J. 2000. Mineral chemistry and pressure-temperature evolution of two contrasting high-pressure-low-temperature belts in the Chonos Archipelago, Southern Chile. Journal of Petrology 41: 309-330.

Willner, A.P.; Thomson, S.N.; Hervé, F.; Massonne, H.-J. 2004a. Converging PT paths of different HP-LT metamorphic units within a Mesozoic accretionary belt (Diego de Almagro Island, Chile): Evidence for juxtaposition during late shortening of an active continental margin. Mineralogy and Petrology 81: 43-84.

Manuscript received: May 03, 2007; accepted: January 30, 2008.
Willner,A.P.; Glodny, J.; Gerya, T.V.; Godoy,E.; Massonne, H.-J. 2004b. A counterclockwise PTt-path in high pressure-low temperature rocks from the Coastal Cordillera accretionary complex of South Central Chile: constraints for the earliest stage of subduction mass flow. Lithos 75 (3-4): 283-310.

Willner, A.; Thomson, S.; Kröner, A.; Wartho, J.-A.; Wijbrans, J.R.; Hervé, F. 2005. Time markers for the evolution and exhumation history of a Late Palaeozoic paired metamorphic belt in North-Central Chile (34․ $35^{\circ} 30$ 'S). Journal of Petrology 46:1835-1858. 